\title{
Genetically Modified Subject Indicator
}

National Cancer Institute

\section{Source}

National Cancer Institute. Genetically Modified Subject Indicator. NCI Thesaurus. Code C158369.

An indication as to whether the study or set contains test subjects that have been genetically modified in some way (e.g., transgenic knock-in, knock-down, etc.). 